\title{
Article
}

\section{In Pursuit of Justice: Debating the Statute of Limitations for Nazi War Crimes in Britain and West Germany during the 1960s.}

\author{
Sharples, Caroline
}

Available at http://clok.uclan.ac.uk/13547/

Sharples, Caroline (2015) In Pursuit of Justice: Debating the Statute of Limitations for Nazi War Crimes in Britain and West Germany during the 1960s. Holocaust Studies: A Journal of Culture and History, 20 (3). pp. 81-108. ISSN 1750-4902

It is advisable to refer to the publisher's version if you intend to cite from the work. http://dx.doi.org/10.1080/17504902.2014.11435376

For more information about UCLan's research in this area go to http://www.uclan.ac.uk/researchgroups/ and search for <name of research Group>.

For information about Research generally at UCLan please go to http://www.uclan.ac.uk/research/

All outputs in CLoK are protected by Intellectual Property Rights law, including Copyright law. Copyright, IPR and Moral Rights for the works on this site are retained by the individual authors and/or other copyright owners. Terms and conditions for use of this material are defined in the policies page. 


\title{
In Pursuit of Justice: Debating the Statute of Limitations for Nazi War Crimes in Britain and West Germany during the 1960s.
}

\begin{abstract}
Up until 1979, the ability of West German courts to prosecute Nazi war criminals was hampered by a Statute of Limitations for acts of manslaughter and murder. Throughout the 1960s, the issue generated considerable public discussion, both within the Federal Republic and among the international community. As prosecutors, politicians, journalists and Holocaust survivors (among many others) debated the need for continued war crimes trials, it was clear that there remained significant limits to western understandings of the Nazi genocide. This article analyses public responses to the Statute in both West Germany and Great Britain and argues that the whole affair has had a crucial impact on the development of international justice and today's pursuit of war criminals.
\end{abstract}

In spring 2013, it was announced that 50 former Auschwitz guards would stand trial in Germany for their role in the Holocaust. ${ }^{1}$ In July that same year, the Simon Wiesenthal Institute launched a poster campaign with the slogan, 'late, but not too late', appealing for the public's help in identifying and tracing any remaining Nazi war criminals. ${ }^{2}$ In each case the message was the same: that the passage of time has not diminished the guilt of these perpetrators, and that old age should not be a barrier to their prosecution. However, the very fact that such trials can still take place at all is highly significant. Indeed, up until 1979, the ability of (West) German courts to prosecute former Nazi perpetrators remained in considerable doubt, hindered by a Statute of Limitations that imposed a strict time limit for investigating cases of murder and manslaughter.

This Statute has received relatively little scholarly attention. Works that have been produced focus predominantly on pertinent legal issues such as post facto legislation, rather than exploring the Statute's broader historical significance. ${ }^{3}$ Notable exceptions to this trend include recent studies by Frank Buscher and Marc von Miquel, although here the emphasis has, quite legitimately, rested upon the political discussions at the heart of the controversy. ${ }^{4}$ This approach, combined with intricate contemporary accounts published by the likes of Rolf Vogel and Karl Jaspers, means that the parliamentary debates on this issue have now been well-documented; their reception elsewhere in society, considerably less so. ${ }^{5}$ 
This, however, has not prevented scholars from making great claims about the Statute's impact on West Germany's relationship with the Nazi past. Peter Reichel argues that the debates opened up a delayed inter-generational dialogue on this period, while Jeffrey Herf suggests the Statute constituted a wake-up call for the Federal Republic, bringing the 'crimes of the Nazi past, as well as the magnitude of judicial failure of the 1950s, to centre stage in West German politics'. ${ }^{6}$ Peter Steinbach sees the eventual changes that were made to the laws governing murder as proof of the Republic's 'commitment to develop a moral-political consciousness of history, as well as a sense of ethical-political responsibility.' ${ }^{7}$ Consequently, as Buscher points out, the Statute, and especially the round of debates heard in 1965, has been depicted as one of the Bundestag's 'finest hours', evidence of liberal democracy in action. ${ }^{8}$ The reality, however, was rather more complicated and closer analysis of the Statute's resonance within wider society highlights the persistence of earlier post-war mythologies, evasions and distortions in respect of the recent past.

This article consequently examines the considerable public discussion generated by the Statute during the 1960s. Drawing upon a variety of sources including government memoranda, opinion poll data and media reports, it explores the arguments put for and against continued war crimes investigations, and asks just where the impetus for continued judicial action was coming from. Above all, this article demonstrates that this was an issue that resonated far beyond the Federal Republic of Germany. Responses in Britain offer a particularly striking case study in this regard. As one of the 'four Great Nations' that had sat in judgement at Nuremberg, and conducted additional war crimes trials within its own zone of occupied Germany, Britain had been at the heart of early policy initiatives against Nazi perpetrators. $^{9}$ As this article will show, there were numerous groups within Britain who deliberately looked to this legacy as proof of the nation's moral duty to pressure the West German government into abolishing the Statute and ensure that the Federal Republic remained on the 'right' path. Given an existing historiography that tends to be quite critical of Britain's record on Nazi war criminals, this episode offers an important reminder that war crimes trials remained a sensitive yet persistent talking point on both sides of the North Sea and debates over the Statute may be seen as a crucial step on the path towards the formation of a wider, western Holocaust consciousness. ${ }^{10}$

\section{$\underline{\text { A 'Guilty Few' }}$}


Arguably, the sheer scale of the Nazi genocide, and the number of perpetrators required to orchestrate it, had been underestimated (or conveniently ignored) from the start. The International Military Tribunal at Nuremberg focussed on the most high-profile, surviving members of the Nazi leadership such as Hermann Göring, Rudolf Hess and Julius Streicher, while Britain's prosecution of Bergen-Belsen personnel in the previous months saw the key defendants demonised in the popular press as 'beasts' and 'monsters'. ${ }^{11}$ Together, these proceedings facilitated the popular belief that the blame for atrocities rested firmly on those at the top, or a sadistic few.

By March 1948, British military courts had tried 909 individuals, compared with the prosecution of 1,672 defendants in the US occupation zone, and 427 in the French zone. Of these, 214 people were sentenced to death, 258 were acquitted, and the remainder received various periods of imprisonment. ${ }^{12}$ The British Foreign Secretary Ernest Bevin noted optimistically, 'the whole process of trying war criminals is now nearly finished... [and] will be completed in a few months'. ${ }^{13}$ The implication (and one that was shared by the West German population) was that all the 'really guilty' individuals had been dealt with; there was simply no need for further proceedings.

The western Allies' commitment to war crimes proceedings certainly transpired to be relatively short-lived, affected in part by the onset of the Cold War. There was no second, Four-Power tribunal and it is notable that many of cases heard in the British zone focussed on crimes perpetrated against Allied personnel, including the infamous murder of British POWs who escaped from Stalag Luft III. ${ }^{14}$ These were war crimes that would have a particular resonance for British audiences back home, where public opinion was already struggling to understand why precious resources should be squandered on the former enemy. A lack of manpower and financial support also meant that British enthusiasm for trials soon waned. ${ }^{15}$

Likewise, the number of war crimes cases being heard before reconstituted West German courts declined sharply during the 1950 s, falling from 68 in 1950 to just 17 by $1957 .{ }^{16}$ The vast majority of these trials also ended with the acquittal of all defendants. ${ }^{17}$ The political climate increasingly favoured a reduction of existing sentences and a general amnesty for former Nazis rather than continued punitive action. Popular references to 'the warcondemned' or 'so-called war criminals' added to the sense that the number of genuine war criminals was very small, and precluded any wider soul-searching regarding the recent past. ${ }^{18}$ 
The legal framework of the new West German state did little to challenge this mode of thinking. The Basic Law of the Federal Republic of Germany, ratified in May 1949, enshrined a Statute of Limitations of fifteen years for cases of manslaughter and twenty years for acts of murder. ${ }^{19}$ Working from the war's end in 1945, Nazi crimes falling into these categories would have to be investigated before 1960 and 1965 respectively. The inclusion of a Statute of Limitations harked back to the Criminal Code of 1871; its re-adoption after the Second World War offered a reminder of the values intrinsic to the formation of the modern German nation, and a return to those laws and civil rights trampled so brutally underfoot by the Nazi regime. National Socialism was thus presented as an aberration in an otherwise healthy German history. The return to the nineteenth century model also meant there was no specific framework for dealing with the peculiar nature of Nazi atrocities; perpetrators of the Holocaust would effectively be treated like any other 'common' criminal.

Conventionally, the 1958 Ulm trial of ten former Einsatzkommando members is regarded as a key turning point in West Germany's engagement with the Nazi past, ushering in a brand new series of war crimes investigations - coordinated by a brand new Central Investigating Agency in Ludwigsburg. ${ }^{20}$ The Ulm case itself came about through the chance discovery of former SS-Oberführer Bernhard Fischer-Schweder, head of an Einsatzkommando unit responsible for the mass murder of Jews and Communists along the Lithuanian border in 1941. Subsequent investigations led to the unearthing of nine more members of his unit, all of whom had been living quietly in West Germany, holding respectable jobs as lawyers, salesmen, policemen or, in one case, an optician. ${ }^{21}$ Their arrest generated a popular sense of shock, anger and dismay. References to 'the murderers among us' were taken up by the West German press, with one publication stating firmly, 'one can only draw a line under the past if one can say, with confidence, that all or at least the predominant part of the concentration camp criminals are punished'. ${ }^{22}$ Opinion polls conducted by the Allensbach Institut für Demoskopie (IfD) in the aftermath of the Ulm case also identified an upsurge in popular interest in the matter and a 54 per cent approval rating for renewed war crimes proceedings. ${ }^{23}$

Yet older perceptions of Nazi perpetrators did not necessarily give way. Critics likened the new wave of investigations to a second, unnecessary denazification process and, as initial moves were made to challenge the Statute of Limitations in the 1960s, talk of a 'guilty few' retained its currency. ${ }^{24}$ The Minister of Justice, Fritz Schaeffer, and the West German 
Ambassador to the United States, Karl Heinrich Knappstein, both insisted that only a very small number of people would actually benefit from the Statute coming into effect. ${ }^{25}$ In 1965, as the deadline for war crimes investigations loomed ever closer, Schaeffer's successor, Ewald Bucher, similarly refuted the need to make any adjustments to West Germany's legal framework, arguing, 'we must be prepared if necessary to live with a few murderers' ${ }^{26}$

\section{Petitioning for Change}

During the 1960s, the West German government faced three choices regarding the prosecution of Nazi perpetrators. It could uphold the Basic Law and allow the Statute to come into effect, thereby bringing an end to war crimes investigations; or it could vote to extend it, granting prosecutors additional time to gather evidence and initiate proceedings against remaining suspects. Alternatively, the Statute could be abolished altogether, enabling war crimes trials to continue unimpeded for as long as necessary. It would become an issue of intense parliamentary debate in West Germany and, it is the contention of this article, one that illustrated the limits of Holocaust awareness in other nations too during this period.

The first motion against the Statute was presented to the Bundestag by the SPD politician Walter Menzel in March 1960, coinciding with the widely-publicised arrest of Adolf Eichmann by Mossad agents in Argentina. ${ }^{27}$ Although there were no legislative decisions at this stage, and the deadline for 'lesser' crimes including acts of manslaughter was allowed to pass, the question of Nazi perpetrators did start to resonate beyond parliamentary and judicial circles. Key names capturing the public's imagination at this time included Josef Mengele, whose post-war fate remained the subject of great speculation; Hans Eisele, the former Buchenwald doctor who fled to Egypt in 1958 to evade war crimes investigators and Karl Silberbauer, the Gestapo officer responsible for arresting Anne Frank, captured in 1963. The former Sobibor and Treblinka commandant Franz Stangl was also hunted during this period, eventually found in 1967, hiding in Brazil.

Consequently, the early 1960s saw increased public dialogue on the war crimes issue and the prescribed cut-off point for dealing with Nazi acts of murder, 8 May 1965, became much more contentious. In 1963 and 1964, for example, members of the German Protestant Church gathered in Düsseldorf for two successive synods that included a discussion on the relevance of the Statute for Nazi atrocities. Despite expressing reservations over the courts' 
ability to uncover the facts so long after the events concerned, the Church took up the cry for continued investigations. A seven page document disseminated through the pulpit, as well as the religious and secular press, stressed how all Germans were implicated in Nazi crimes, rued the Church's failure to take concerted action at the time, and insisted that 'in any society, evil must be recognised as abominable and must be punished accordingly'. ${ }^{28}$ The wider West German media was also generally supportive of further trials, regardless of their political leanings. Der Spiegel, for example, framed a fourteen page article on the Statute with an arresting front cover photograph depicting three elderly figures about to be shot by Nazi commandos, reminding people of the brutal nature of the crimes under discussion. ${ }^{29}$

Members of the Bundestag were allowed a free vote on the Statute in the spring of 1965. Opinion was split between and within political parties. Broadly speaking, though, the conservative CDU tended to argue that prosecutors had now had sufficient time to bring suspects to account and the Statute should therefore be allowed to come into effect. The FDP also wanted to uphold the Statute, maintaining that any other move would undermine public faith in the rule of law. The SPD, though, generally agreed with survivors' groups that the magnitude of Nazi crimes must override other concerns, that the original criminal code had been drawn up to deal with crimes committed in 'everyday' circumstances rather than a racial war of extermination, and that investigations into those responsible should thus continue. ${ }^{30}$ Observers within the British Foreign Office summed up the prevailing mood:

The question has placed the Federal Government in a dilemma. On the one hand, they do not wish to be exposed to the charge that they are using the Statute of Limitations in order to cover up Nazi crimes... On the other hand, they do not want these trials, with all the received publicity about German wartime atrocities that accompanies them, to drag on indefinitely year after year and so to keep alive in the world the feeling that the Germans are a particularly cruel and evil race who should not be trusted. ${ }^{31}$

Reporting for the Jewish Chronicle, Eleonore Sterling suggested that there was a 'striking discrepancy' between public and private opinion on the war crimes issue. ${ }^{32}$ Buscher too has argued that 'the awareness shown by some politicians, journalists, legal experts and intellectuals failed to have a trickle-down effect' and that 'the average citizen refused to break with the Vergangenheitspolitik of the 1950s' ${ }^{33}$ Opinion polls seem to confirm that the effects of the Ulm and Eichmann trials quickly wore off to be replaced by a sense of "trial fatigue'. In October 1963, the IfD found that just 34 per cent of people questioned approved 
of continued trials. ${ }^{34}$ In May 1965, as parliamentary debates over the Statute reached fever pitch, pollsters again took to the streets to gauge public feeling on the matter. 344 people over the age of 21 were interviewed across the Federal Republic, with the results showing 32 per cent in favour of further trials, and 57 per cent preferring to draw a final line (Schlußstrich) under the whole Nazi era. ${ }^{35}$ The sample for this survey was, admittedly, extremely small, yet the findings were borne out by other opinion researchers. The Wickert Institute, for example, found 37 per cent of men and just 22 per cent of women supporting continued war crimes proceedings. ${ }^{36}$

Significantly, there tended to be a rather different set of results if people were interviewed in relation to a specific case. During the Auschwitz trial, for example, DIVO found 53 per cent of respondents articulating the need for such proceedings to be continued - and staff noted that even this figure was in marked decline to the responses generated by the Eichmann trial three years earlier. ${ }^{37}$ Arguably, it was easier for people to agree with the punishment of a particularly notorious individual or set of crimes, cases that were already attracting considerable media attention, than the somewhat abstract principle of continued war crimes investigations. Again, there was perhaps a sense that these were isolated affairs, with the defendants continuing to fit the mould of a radical 'few'. By contrast, altering the Statute would imply that there was a wider set of responsibilities to contend with, and this was a far more unsettling prospect.

The apparent reluctance to challenge the Statute of Limitations stemmed from a variety of concerns. There were legitimate questions over the reliability of witness and defendant memories so long after the commission of the crimes and the likelihood of securing a successful prosecution. ${ }^{38}$ It could also be argued that continued trials served no social purpose; the perpetrators of Nazi crimes had (as illustrated so keenly with the Ulm case) long since been reintegrated into the fabric of West German society. ${ }^{39}$ Furthermore, there were genuine concerns about the legality of making any alterations to the Statute. War crimes trials were already clouded by debates over retrospective legislation, and wider events in 1960s West Germany suggested that the nation's fledgling democracy was coming under increased attack. 1962 saw the Spiegel Affair and the State's encroachment on press freedom, while 1966-68 witnessed the controversial Grand Coalition, Extra-Parliamentary protests and Kurt Georg Kiesinger's Emergency Laws. Thus, while foreign pressure groups argued that extending or abolishing the Statute of Limitations would prove West Germany's 
democratic credentials, West Germans themselves feared it would have exactly the opposite effect. Indeed, regarded in this light, it would appear that people were keen to learn from the past and avoid any further situations where laws and civil liberties could be swept aside.

However, debates over the Statute also enabled the persistence of older mythologies, including efforts to relativise Nazi atrocities. Amid the IfD's 1965 survey, for example, two thirds of those opposed to further trials based their conviction on the simple refrain that other war crimes had been convicted and gone unpunished. References to the bombing of Dresden or the atomic explosions over Hiroshima and Nagasaki harked back to claims of victors' justice that had been circulating since 1945. Likewise, 57 per cent of participants in the survey argued that Germans should stop 'dirtying their own nest' (Nestbeschmutzen), a popular sentiment of the post-war era that criticised those who would persist in muckraking and bringing up the past. ${ }^{40}$

Even when people did voice support for changing the Statute, their reasoning remained quite introspective. Over a third of those questioned by the IfD pointed to the potential damage to the Federal Republic's world status, or the shame 'we as Germans' would face if prosecutions ended, and 14 per cent argued that world opinion demanded action. Such concerns for West Germany's image abroad had been seen before. In the run up to the Eichmann trial, the then chancellor, Konrad Adenauer, expounded on this very issue and several West German newspapers reported on the effects that much-publicised case had upon American views of the German people. ${ }^{41}$ Similar thinking was articulated in a March 1964 conversation between a British embassy official and Dr Erwin Schule, director of the Ludwigsburg Zentrale Stelle:

If it were really true that the majority of West Germans did not wish investigations of this nature to continue, there would, he [Schule] said, be no investigations because the popular will would be expressed in amnesty legislation... What he did often find when addressing public audiences was feelings of uneasiness and shame which translated themselves into the suggestion that such proceedings should be hushed up so as not to drag the name of Germany in the mud. ${ }^{42}$

Such comments suggest an intriguing potential relationship between West German policy and external, foreign opinion. There was an ongoing tension between being seen to do the right thing, and the fear of injuring the nation's reputation by allowing it to be continually 
associated with the crimes of the previous regime - but would this be enough to abolish the Statute?

\section{British Responses to the Statute}

As the politicians and general population of the Federal Republic wrestled with the question of continued war crimes investigations, other nations also took up the issue. The 1960s are frequently pinpointed as an era of sudden, critical engagement with the National Socialist legacy and a time when the very concept of 'The Holocaust' gained currency in the western world. Public demonstrations over the Statute of Limitations, as seen, for example, on the streets of Paris and Los Angeles, can thus be linked to the lingering effects of the 1961 Eichmann trial, a new growth in survivor testimony and the emergence of a younger generation prepared to ask difficult questions about the recent past. ${ }^{43}$ Public rallies were accompanied by a host of letters, petitions and resolutions sent either directly to Bonn or to West German embassies throughout the world, trying to persuade the Federal German government to overturn the Statute. British Labour politicians had already telegraphed their support for Menzel's 1960 presentation to the Bundestag and in December 1964, David Ennals, MP for Dover and himself a former prisoner of war, led another petition calling on West Germany to maintain its investigations into Nazi war criminals. 53 of Ennals's fellow MPs signed the petition, including Philip Noel Baker who had famously urged the House of Commons into action after Kristallnacht in $1938 .^{44}$ The same month saw Robert Kempner, former Assistant Chief Counsel for the US Prosecution at Nuremberg, taking to North German radio, addressing his concerns about the Statute direct to the West German people. ${ }^{45}$ Elsewhere, the renowned Nazi-hunter Simon Wiesenthal orchestrated a letter-writing campaign, sending over three hundred missives to 'influential' people around the globe and urging them, in turn, to lobby the Federal German government. ${ }^{46}$

As the involvement of Kempner, Wiesenthal and Noel Baker illustrates, many of the voices heard during this affair came from individuals with a prior history of trying to draw attention to Nazi crimes. Survivors' groups, Jewish organisations and trade unions were particularly vocal, understandably wanting to see justice delivered on behalf of their murdered brethren and political comrades. There was also an immense amount of pressure from the Soviet Union and its satellite states, although this was unsurprising given the existing ideological tensions and a history of East German critiques on its western counterpart's handling of the 
past. ${ }^{47}$ The USSR heard public speeches from its own Nuremberg prosecutors, alongside statements from former soldiers and concentration camp survivors and the screening of a documentary film on Auschwitz. ${ }^{48}$ China, meanwhile, attacked the Statute as 'monstrous', a 'brazen defiance of international law' and 'sacrilege to millions upon millions of innocent victims'. ${ }^{49}$ Most of these actions were condemned by western observers as Communist 'propaganda', but the potential ramifications of the Statute could not be so easily dismissed.

Advocates of continued war crimes investigations stressed a sense of duty towards the victims of the Third Reich, and the distinctiveness of Nazi atrocities. The Archbishop of Boston, for instance, proclaimed that 'there should be no moratorium on an evil as great as genocide... The most monstrous event in our contemporary history must be answered in justice as long as our generation is alive. ${ }^{50}$ There was also an oft-repeated argument that continuing war crimes trials were imperative for demonstrating the Federal Republic's commitment to democratic values and the sincerity of its attempts to atone for the recent past. A letter writer to the New York Times argued 'West Germany can only become a deep-rooted democracy provided that she purifies herself from the poison in her bloodstream'. ${ }^{51}$ Such arguments were routinely couched in the rhetoric of a German 'rebirth' or 're-civilisation', and were not confined to external critics. During the March 1965 Bundestag debates, the CDU politician and legal scholar Ernst Benda launched an impassioned plea for amending the Statute, asserting: 'one unpunished murderer among us is one too many, and if we abandon the hunt for them, we might as well abandon the republic and revert to living in caves. $^{52}$

In a similar vein, the early 1960s saw various organisations, including the Institute of Jewish Affairs, the Board of Deputies of British Jews and the Wiesenthal Centre, writing to governments around the world to ascertain whether they too had a Statute of Limitations as part of their criminal code. The results became further grist to the pro-trial campaign: if other nations did not feel the need for a time limit on acts of murder, why should the Federal Republic? Again, the matter became framed in terms of West Germany's own international standing; its rehabilitation would not be complete until it came fully into line with the rest of the democratic world. ${ }^{53}$ However, as an examination of British responses to the Statute reveals, pressure was not just being directed at West Germany. 
Mainland Britain did not have the same experiences of occupation or collaboration to contend with as its European neighbours after 1945. Instead, the emphasis was on a more celebratory narrative - Britain as victor, liberator and upholder of justice. However, it is precisely due to this last role that many felt compelled to look to Britain for guidance on the Statute of Limitations. In 1964-5, the government faced numerous requests by domestic and international campaigners to ensure that the Federal German government came 'to a correct appreciation of the situation'. ${ }^{54}$ Much of the external lobbying stemmed from Eastern bloc countries, but there were appeals from victim groups as well who argued that 'pressure... by a friendly power such as the United Kingdom might be more effective' in influencing West German policymakers than communist agitation. ${ }^{55}$ There was also a repeated emphasis on the nation's legal obligations to intervene. A note submitted to the British Embassy in Prague, for example, urged the British government to act on the basis that it was a signatory to the 1945 London Agreement. ${ }^{56}$ This provoked the retort that Britain had already discharged its duties under that charter, having played a full role in the United War Crimes Commission, the International Military Tribunal at Nuremberg and the military courts within their former occupation zone. The investigation into Nazi perpetrators, officials argued, was now an entirely German matter. ${ }^{57}$ Nonetheless, criticisms of Britain's stance continued, with the domestic press suggesting that the current fiasco was a direct result of the Allies' own failings in the immediate aftermath of the war. The Guardian commented:

The Western Powers should not forget that in their day, they were none too quick off the mark in the same field. Undoubtedly, they allowed far too many former Nazis to creep back into positions of influence... The sovereign West German government could hardly be expected to weed out men whom the Allies had permitted to survive. ${ }^{58}$

Within Britain, calls to intercede on the Statute were increasingly mounted by representatives of the Anglo-Jewish community, politicians and various workers friendly societies. The National Union of Furniture Trade Operatives - which had a 1,400 strong membership - was among those urging the Prime Minister to 'join with other nations' and demand that the Federal Republic extend the Statute. ${ }^{59}$ In the House of Commons, the Labour MP for Wolverhampton North East, Renée Short, inquired on two separate occasions as to whether the issue would be discussed during Wilson's forthcoming visit to Bonn. ${ }^{60}$ By January 1965 , observers within the Foreign Office conceded 'public interest in this country is growing' and 'we shall have to work out our attitude to this question'. ${ }^{61}$ 
All of this supports the view, put forward by David Cesarani among others, that the 1960s were far from constituting an era of British 'silence' on the Holocaust. ${ }^{62}$ It is clear, though, that the impetus for most of this discussion was coming from the bottom up; the government itself was understandably reluctant to be seen as meddling in another nation's domestic affairs. When Barnett Janner suggested that an intercession by the Prime Minister might strengthen Chancellor Erhard's hand in the forthcoming Bundestag debates, Wilson rejoined that such measures would be 'unhelpful and ill-advised'. ${ }^{63}$ When Wilson and Erhard finally met in February 1965, the Prime Minister was quick to reassure him that he had 'no desire at all to interfere'. ${ }^{64}$ On the one hand, the British stance was pragmatic, suggesting lessons had been learned from the occupation period when West Germans frequently dismissed Allied measures as nothing more than 'victors' justice'. On the other hand, though, British reticence persisted even when directly approached for help by the Federal German government.

In November 1964, West Germany responded to the growing international pressure by issuing an appeal for other nations, particularly the former Allies, to release any relevant documents that could aid war crimes investigators. Internal correspondence between the British Ministry of Defence and the Foreign Office reveals that the UK held material relating to some 280 cases of 'illegal killing' that had not been followed up during the occupation period. There was some debate, though, as to what, if anything, should be done about this. 'Either we must tell the Germans that we still have a number of documents which it would take two or three months to go through... or we must omit all reference to the existence of these documents and give a more general reply on the lines that we have been unable so far to find anything which would be of interest to the Germans', noted officials. ${ }^{65}$ The time required to peruse the material was only part of the issue; there were also concerns about political security. The Ministry of Defence declared that German experts 'certainly cannot' be granted access to the material themselves, while, for the Foreign Office, W.B.J Ledwidge appealed for more leeway, pointing out, 'the United States Government have already done this [opened their archives] and we should not seem to be less forthcoming or there may be press and parliamentary concern. ${ }^{66}$ This comment again sums up much of the political response to the Statute both in Britain and in West Germany: public relations assumed a greater importance than any moral obligation to ensure Nazi perpetrators could not evade justice. 
While Britain dragged its heels, suggesting that material may already be in Bonn or with the UNWCC, or offering to consult its records in respect of any 'specific case which the Federal Government is able to name', the USSR launched a scathing attack on the whole documents issue. For the Soviets, the West German request for assistance was a ploy, 'an improper attempt to disguise the actual amnesty of the fascist murderers and to whitewash its unlawful actions in the eyes of world public opinion'. ${ }^{67}$ In reality, the information request constituted a crucial effort to 'stop the clock' running down on Nazi perpetrators as, under West German law, the Statute of Limitations would be interrupted at the beginning of a criminal investigation. In theory, the move could have enabled West Germany to enjoy the best of both worlds, using the existing system to prosecute more war criminals while sparing the nation any challenge to its legal framework. The information request also underscores the constraints that West German prosecutors were working under at the time. The realities of division, not to mention the chaos at the end of the war, meant evidence was not in any single, easy to access archive.

When analysing the various petitions against the Statute during this period, it is important to recognise that there was no simple dichotomy between governments and various pressure groups. Even among those lobbying for continued trials, there was indecision as to the best means of achieving this. The Board of Deputies of British Jews, for example, saw debate between a leadership that preferred to adopt a resolution and make gentle overtures to the West German Ambassador, and a membership keen to generate greater publicity for the campaign through public meetings, vigils and a march on the West German embassy. In January 1965, the Workers' Circle Friendly Society opined that the issue 'merits much more action and publicity', while the Leeds Jewish Representative Council questioned whether local action could advance the campaign. ${ }^{68}$ The Deputy for Hightown Central Synagogue in Manchester ultimately decided to organise his own silent march of protest. ${ }^{69}$ In trying to quell some of these elements, the Board was anxious to avoid any possible disruption to the diplomatic process, or doing anything that might create the impression that they themselves 'had not been active in the matter' ${ }^{70}$

\section{$\underline{\text { Making A Decision }}$}

It was, of course, relatively easy for foreign observers to weigh in and critique the Federal Republic's handling of the past, yet ultimately the decision about the Statute of Limitations 
was one for the West Germans alone. In March 1965, after prolonged parliamentary discussions, the Bundestag agreed on a compromise, voting 344 to 96 to extend the Statute of Limitations to 31 December 1969. This meant the clock would effectively be reset to start its twenty year countdown from the moment of the Federal Republic's formation in 1949, rather than the war's end in 1945, thereby giving prosecutors an additional four years to conduct their investigations. The justification for this move was that the courts had been in no position to operate properly amid the upheaval of the immediate post-war era. Legal critics could be appeased by the fact that there was already a precedent for amending the Statute's start date; the original deadline, set from end of the Third Reich, had itself deviated from standard procedure which would have started the Statute from the time of the actual commission of the crimes. However, the result was not universally popular and the Minister for Justice, Ewald Bucher, resigned in protest, adding to the cracks then emerging between the CDU-FDP coalition.

Over 120 cases were heard before West German courts between May 1965 and May 1969, encompassing a range of Nazi atrocities from the mass shootings committed by police battalions and Einsatzgruppen along the Eastern Front, to crimes perpetrated within specific camps such as Flossenburg, Mauthausen and Auschwitz. ${ }^{71}$ Consequently, the extent of the Holocaust was being documented in increasing detail. It was not long, though, before the Statute of Limitations re-entered public discourse. This next series of debates over its utility echoed much of what had gone before in 1964-5, although Die Zeit also engaged with the new international climate of détente, stressing how the Soviet Union was only now opening its archives and allowing West German prosecutors access to new evidence. More time, it was argued, was essential to sift through this material; the Statute of Limitations would have to be re-examined. ${ }^{72}$

This time, though, it was not simply a question of whether to continue trials but also just what, exactly, constituted an act of murder. Under Clause 50 of the West German Penal Code, the maximum penalty facing those convicted of being an accessory to murder was likely to be the same as that for the main offender. In September 1968, however, amid large scale investigations into the administrative personnel of the RSHA, this article was amended. If the court was not satisfied the defendant had acted out of 'base motives', the highest penalty he or she could now receive would be equal to the fifteen year prison sentence afforded to manslaughter cases. The Statute of Limitations for that category of crimes had 
already come into effect in May 1960. Consequently, many 'desk murderers', together with those who simply claimed to have been following orders, could evade punishment; the vital role of middle class professionals in the development and implementation of the 'Final Solution' continued to be obscured. ${ }^{73}$

The distinction between callous killers acting out of 'blood lust' and those merely doing their 'duty', had already become a marked feature of war crimes proceedings. During the 1963-5 Frankfurt Auschwitz trial, for example, the emphasis in both the press and the courtroom was placed firmly on what Rebecca Wittmann has termed the 'excess perpetrators', individuals who went beyond the bounds of their 'job description' to commit acts of gross violence. Defendants who showed a rare moment of mercy towards their victims received favourable treatment before the courts compared with colleagues who had seemingly taken great pleasure in devising their own unique brand of torture. ${ }^{74}$ Likewise, numerous trials still saw defendants depicted as 'devils' within media reports - a dehumanising rhetoric that enabled the 'ordinary' population to distance themselves from these characters and avoid any deeper, critical reflection on how the Holocaust had been made possible.

On 26 June 1969, the Bundestag again voted to extend the Statute, this time for an additional ten years. 279 members supported the bill, 126 opposed it and there were 4 abstentions. A decade later, the vote was much closer, yet finally, on 3 July 1979, the application to remove the Statute for all cases of murder was passed after a ten hour parliamentary debate, 255 votes to $222 .{ }^{75}$ The path was now free for West German prosecutors to continue their work in relation to the crimes of National Socialism. Why the change of heart? Clearly, the increased opposition vote between 1969 and 1979 demonstrates that the problem of Nazi war criminals remained highly contentious; public opinion too was shown as increasingly opposed to further legal proceedings. ${ }^{76}$ To some extent, the answer may rest with broader cultural developments taking place at this time, particularly the screening of the American television miniseries, Holocaust in the spring of 1979 which is frequently credited with effecting a shift in popular attitudes to the Nazi past. ${ }^{77}$ Certainly, correspondence generated by British government officials, delegates within the Council of Europe and members of the public during this last round of debates routinely referenced the Statute within the context of Holocaust. ${ }^{78}$ While the victims of the Nazi genocide had remained anonymous, distant entities during earlier discussions, the fictional Weiss family depicted in Holocaust encouraged public empathy and, in this climate, the idea that those responsible for atrocities 
should be brought before a court of law regained some momentum. Chancellor Helmut Schmidt underscored Holocaust's impact when he told the Bundestag:

This film forces one to think critically, to think morally... thinking is needed also in view of the decision each of us will have to make for himself late this year regarding the Statute of Limitations for the prosecution of murder. ${ }^{79}$

Analysing responses to the Statute between 1978-9 also reveals some striking developments from the 1965 debates. It is notable, for instance, that a significant number of petitions addressed to the British and West German governments now came from younger people. The British government, for instance, received petitions from student unions and lecturers at the Universities of Birmingham, Salford, Warwick and Queen's, Belfast. ${ }^{80}$ A shift in rhetoric was also evident, with an increased tendency to stress the universal nature of the war crimes issue. Here, the prosecution of Holocaust perpetrators was juxtaposed with more recent atrocities committed in Vietnam and Cambodia, as well as electoral successes enjoyed by Far Right groups such as the National Front in Britain; consequently, the Parliamentary Assembly of the Council of Europe noted that the Statute was not just about held relevance 'for history, for the present and the future' and 'for all countries'. ${ }^{81}$ This was an issue that now went beyond Germany and the Second World War.

Foreign pressure also appeared to gain significance during this final round of debates. Speaking at a synagogue on the anniversary of Kristallnacht in November 1978, Chancellor Schmidt pledged that politicians and legislators would 'listen to what our Jewish citizens, our friends in Israel and our neighbours have to tell us' and 'obtain advice and participation from many sources'. ${ }^{82}$ This comment was a green light to lobbying parties such as the Board of Deputies of British Jews who sent a copy of Schmidt's speech to the Foreign Secretary, David Owen, to justify advances to the West German Ambassador. ${ }^{83}$ Wiesenthal, meanwhile, organised a visit of US politicians, civil rights leaders and Jewish representatives to Bonn to press the government on the Statute, and the Auswärtiges Amt received further petitions from the US House of Representatives, the Polish, Israeli and Luxembourg governments and 'tens of thousands of privately written protests'. ${ }^{84}$ Observers within the British embassy in Bonn concluded, 'there can be no doubt that the government are very conscious of these external aspects and are taking them fully into account', and Schmidt did reference the 'enormous number of petitions' received from within and outside West Germany during a speech to the Bundestag in March 1979. ${ }^{85}$ 
Against this background, the British government adopted a slight change in its own tactics. Alongside the standard response that it would be inappropriate for Britain to involve itself in an internal, German matter, petitioners were now invited to direct their concerns straight to the Federal German government. In February 1979, for example, Lord Goronwy-Roberts wrote that 'there has been some recent well published evidence of the degree of concern which continues to be felt among people of all ages in the Federal Republic about this kind of issue'; sensing that the time was ripe for change, Foreign Office staff began to encourage, rather than shut down, protests by academics, MPs, synagogues and the Association of Jewish Ex-Servicemen. ${ }^{86}$

\section{Conclusion}

The periodic controversies over the Statute of Limitations for Nazi crimes demonstrate that there was no linear pattern of ever-critical engagement with the Nazi past. A series of silences and distortions continued to hold sway within the Federal Republic, while the wider, western world also struggled to grasp the enormity of the Holocaust. Britain, for instance, continued to cling to the concept of a 'guilty few', and seemed loathe to dwell the past, with government staff seemingly taken aback by the levels of interest displayed by certain MPs, Anglo-Jewish groups, trade unionists and others. Britain's response to the Statute of Limitations thus provides a valuable context for exploring later developments in the nation's Holocaust consciousness, including the protracted passage of the War Crimes Act in 1991.

At the same time, debates over the Statute are also crucial for understanding contemporary responses to genocide, having provided the framework for today's international justice model. It was in direct response to the prospect of former Nazis evading justice through a legal loophole that the UN introduced the Convention on the Non-Applicability of Statutory Limitations to War Crimes and Crimes Against Humanity in 1968, and the European Convention on the same issue was opened for signatures in $1974 .{ }^{87}$ More recently, the notion that acts of genocide should be exempt from any legal prescription was further cemented with the Rome Statute of the International Criminal Court. ${ }^{88}$ None of these measures has the full backing of the international community, and there remains significant debate over the necessity of such measures. War crimes investigations and prosecutions too, remain imperfect affairs. Nonetheless, the very existence of these conventions has symbolic value, designed to show would-be transgressors that human rights violations will not go unpunished 
and act as some form of deterrent. All of this can be traced directly to the legacy of the Holocaust and the gradual realisation that unprecedented atrocities called for new forms of legislation. It is in this context, that the significance of West Germany's Verjährung debates of the 1960s becomes truly recognised.

I wish to thank Tim Grady, Neil Gregor, James Campbell, Andrew Johnstone and the anonymous reviewers for this journal for their comments on earlier versions of this article.

${ }^{1}$ See, for example, 'Fahndung nach Nazi-Verbrechern: Ermittler sind 50 KZ-Aufsehern auf der Spur', Der Spiegel, (6 April 2013).

${ }^{2}$ Simon Wiesenthal Centre, 'Under the Slogan "Late But Not Too Late," the Wiesenthal Center Launches a Publicity Campaign in Germany for Operation Last Chance II', 21 July 2013, http://www.wiesenthal.com/site/apps/nlnet/content2.aspx?c=lsKWLbPJLnF\&b=4441467\&ct=13224167 (accessed 29 May 2014).

${ }^{3}$ Existing works stem largely from legal studies: J.E.S Fawcett, 'A Time Limit for Punishment of War Crimes?', British Institute of International and Comparative Law, 14, no. 2 (1965): 627-632; Robert A. Monson, 'The West German Statute of Limitations on Murder: A Political, Legal and Historical Exposition', American Journal of Comparative Law, 30, no. 4 (1982): 605-625; Martin Clausnitzer, 'The Statute of Limitations for Murder in the Federal Republic of Germany', International and Comparative Law Quarterly, 29, nos. 2-3 (1980): 473-479.

${ }^{4}$ Frank Busher, "'I Know I Also Share the Guilt": A Retrospective of the West German Parliament's 1965 Debate on the Statute of Limitations for Murder', Yad Vashem Studies, 34 (2006): 249-292; Marc von Miquel, Ahnden oder Amnestieren? Westdeutsche Justiz und Vergangenheitspolitik in den sechziger Jahre (Gottingen: Wallstein Verlag, 2004) and 'Explanation, Dissociation, Apologia: The Debate over the Criminal Prosecution of Nazi Crimes in the 1960s', Philipp Gassert and Alan E. Steinweis (eds), Coping with the Past: West German Debates on Nazism and Generational Conflict, 1955-1975 (New York: Berghahn, 2007): 50-63.

${ }^{5}$ Jürgen Baumann, Der Aufstand des schlechten Gewissens: ein Diskussionsbeitrag zur Vejährung der NSGewaltverbrechen (Bielefeld: Gieseking, 1965); Rolf Vogel, Ein Weg aus der Vergangenheit: Eine Dokumentation zur Verjährungsfrage und zu den NS-Prozessen (Frankfurt am Main: Ullstein, 1969); Karl Jaspers, Die Schuldfrage: Für Völkermord gibt es keine Verjährung (Munich: Piper Verlag, 1979). Historical works which afford the Statute fleeting mention include Helmut Dubiel, Niemand ist frei von der Geschichte: Die nationalsozialistische Herrschaft in den Debatten des Deutschen Bundestages (Munich: Carl Hanser, 1999): 103-110; Bernd Hey, 'Die NS-Prozesse - Versuch einer juristischen Vergangenheitsbewältigung', Geschichte in Wissenschaft und Unterricht, 6 (1981): 338-340, 345; Christa Hoffmann, Stunden Null?

Vergangenheitsbewältigung in Deutschland, 1945 und 1989 (Bonn: Bouvier, 1992): 167-169; Harold Marcuse, Legacies of Dachau: The Uses and Abuses of a Concentration Camp, 1933-2001 (Cambridge: Cambridge University Press, 2001): 214-216; Rebecca Wittmann, Beyond Justice: The Auschwitz Trial (Cambridge, Massachusetts: Harvard University Press, 2005): 48-53. Again, though, the chief focus in all these references is on the Bundestag.

${ }^{6}$ Peter Reichel, Vergangenheitsbewältigung in Deutschland: Die Auseinandersetzung mit der NS Diktatur von 1945 bis heute (Munich: C.H. Beck, 2001): 182-198; Jeffrey Herf, Divided Memory: The Nazi Past in the Two Germanys (Cambridge, Massachusetts: Harvard University Press, 1997): 335-342.

${ }^{7}$ Peter Steinbach, Nationalsozialistische Gewaltverbrechen: Die Diskussion in der deutschen Öffentlichkeit nach 1945 (Berlin: Colloquium Verlag, 1981): 67.

${ }^{8}$ Buscher, "I Know I Also Share the Guilt", 253.

${ }^{9}$ This term was used repeatedly in Justice Jackson's opening statement before the International Military Tribunal, 21 November 1945: Trial of the Major War Criminals Before the International Military Tribunal (The Blue Set), 2 (Nuremberg: IMT, 1947): 98-155.

${ }^{10}$ See: Donald Bloxham, 'British War Crimes Trial Policy in Germany, 1945-1957: Implementation and Collapse', The Journal of British Studies, 42, no. 1 (2003): 91-118; David Cesarani, Justice Delayed: How Britain became a Refuge for Nazi War Criminals (London, 2001).

${ }^{11}$ Raymond Phillips (ed.), Trial of Josef Kramer and Forty-Four Others: The Belsen Trial (London: W. Hodge, 1949). For similar styles of reporting, see: Alexandra Przyrembel, 'Transfixed by an Image: Ilse Koch, the "Kommandeuse of Buchenwald"', German History, 19, no. 3 (2001): 369-399. 
${ }^{12}$ United Nations War Crimes Commission, 'Progress Report of War Crimes Trials from Data Available on March $1^{\text {st }} 1948$ ', The History of the United Nations War Crimes Commission (London: HMSO, 1948) p.518. ${ }^{13}$ The National Archives, London (hereafter TNA), CAB/129/26: Ernest Bevin, 'Death Penalty in the British Zone of Germany', 23 April 1948. The opening of the IMT at Nuremberg saw similar, widespread hopes that the process would take a maximum of three months - Caroline Sharples, 'Holocaust on Trial: Mass Observation and British Media Responses to the Nuremberg Tribunal, 1945-6', C. Sharples \& O. Jensen (eds), Britain and the Holocaust: Remembering and Representing War and Genocide (Basingstoke: Palgrave Macmillan, 2013): 31-50.

${ }^{14}$ Around 40 per cent of those executed by the British in Hameln, for example, had committed crimes against Allied nationals. See: TNA F01060/239-243: Executions Policy and Peter Krone ed.,

'Hingerichtetengräber' auf dem Friedhof Wehl, Hameln: Historische Dokumentation (Hameln: Stadtarchiv, 1987).

${ }^{15}$ Donald Bloxham, “"The Trial that Never Was": Why There Was No Second International Trial of Major War Criminals at Nuremberg', History, 87 (2002): 41-60.

${ }^{16}$ On the early history of war crimes trials before West German courts, see Devin O. Pendas, 'Retroactive Law and Proactive Justice: Debating Crimes Against Humanity in Germany, 1945-1950', Central European History, 43 (2010): 428-463.

${ }^{17}$ C.F. Rüter and D.W. de Mildt (eds), Justiz und NS-Verbrechen: Sammlung deutscher Strafurteile wegen nationalsozialistischer Tötungsverbrechen 1945-1966. Register zu den Bänden I-XXII (Amsterdam: APA Holland University Press, 1998). The belief in a 'guilty few' had an important domestic utility: enabling people to return to pre-war positions in public life with no questions asked eased the process of West German reconstruction and transition to democracy - see: Hermann Lübbe, 'Der Nationalsozialismus im Deutschen Nachkriegsbewusstsein', Historische Zeitschrift, 236 (1983): 579-599.

${ }^{18}$ On the amnesty issue, see: Norbert Frei, Adenauer's Germany and the Nazi Past: The Politics of Amnesty and Integration, translated J. Golb (New York: Columbia University Press, 2002).

${ }^{19}$ Article 67 of the Criminal Code stated: 'Prosecution shall be barred by time limitation after twenty years in the case of serious offences (Verbrechen) punishable by confinement in a penitentiary for life; after fifteen years in the case of serious offences for which the maximum penalty is deprivation of liberty for a term of more than ten years; and after ten years in the case of serious offences punishable by the deprivation of liberty for a shorter term' - Robert H. Miller, 'The Convention of the Non-Applicability of Statutory Limitations to War Crimes and Crimes Against Humanity', American Journal of International Law, 65, no. 3 (1971): 478-479.

${ }^{20}$ On the impact of the Ulm trial, see: Jean-Paul Bier, 'The Holocaust, West Germany and Strategies of Oblivion, 1947-1979' in Anson Rabinbach and Jack Zipes (eds), Germans and Jews since the Holocaust: The Ongoing Situation in West Germany (New York: Holmes \& Meier, 1986), 189; Dick de Mildt, In the Name of the People: Perpetrators of Genocide in the Reflection of their Post-war Prosecution in West Germany. The 'Euthanasia' and 'Aktion Reinhard' Trial Cases (The Hague: Martinus Nijhoff, 1996), 27; Ulrich Brochhagen, Nach Nürnberg: Vergangenheitsbewältigung und Westintegration in der Ära Adenauer (Berlin: Ullstein, 1999) 292; Caroline Sharples, West Germans and the Nazi Legacy (New York: Routledge, 2012), 30-50.

${ }^{21}$ For details on these arrests, see Adalbert Rückerl, The Investigation of Nazi Crimes, 1945-1978: A Documentation, translated by D. Rutter (Karlsruhe: CF Müller, 1979), 48.

22 'Zentrale Ermittlungsbehörde?', Trierischer Volksfreund (15 September 1958). See also 'Zentrale Ermittlungsbehörde muß klarheit uber NS-Verbrechen schaffen', Stuttgarter Zeitung (3 September 1958); 'Nicht zögern', Freie Presse (12 September 1958); 'Justiz und Konkurmasse', Frankfurter Neue Presse (3 October 1958); ‘Aufräumen' and 'Die Vergangenheit laßtet', Frankfurter Allgemeine Zeitung (6 and 13 October 1958).

${ }^{23}$ Survey of 2000 people reported in Elisabeth Noelle and Erich Peter Neumann (eds), Jahrbuch der offentlichen Meinung, 1958-1964 (Allensbach: Institut für Demoskopie, 1965), 211.

${ }^{24}$ See, for example, 'Stimmen zu den Urteilen im Ulmer Proze $\beta$ ', Müncher Merkur (13 September 1958). For more on the reception afforded to the Central Investigating Agency, see: Kurt Schrimm and Joachim Riedel, '50 Jahre Zentrale Stelle in Ludwigsburg', Vierteljahrshefte für Zeitgeschichte, 56, no. 4 (2008): 525-555; Rüdiger Fleiter, 'Die Ludwigsburg Zentrale Stelle und ihr politisches und gesellschaftliches Umfeld', Geschichte in Wissenschaft und Unterricht, 53, no. 1 (2002): 32-50.

${ }^{25}$ Cited in Kurt R. Grossman ed., Digest on Germany and Austria: Jewish Claims and Related Subjects. Special Issue: The Statute of Limitations, (30 January 1965), London Metropolitan Archives (hereafter LMA) ACC/3121/E4/470: Statute of Limitations.

${ }^{26}$ Cited in TNA FO371/183153: Germany: Letter from A.W. Rhodes, British Embassy, Bonn to R.G. Sheridan, Western Department, Foreign Office, London, 23 January 1965. Bucher and the FDP remained opposed to altering the Statute throughout the debates. 
${ }^{27}$ Grossman, Digest on Germany and Austria. Eichmann was specifically mentioned in this presentation, but to no avail. Menzel was a member of the Parliamentary Committee, closely involved in the Basic Law at the founding of the Federal Republic and recognised as one of the 'fathers' of the West German Constitution. Given this background, his campaign to alter the Statute of Limitations gains added significance, and suggests that the peculiarity of National Socialist crimes had not been considered at the Basic Law's inauguration. 28 'Das Wort des Rates der EKD zu den NS-Verbrecher-Prozessen', Kirchliches Jahrbuch (1963): 75-79. In 1964, the Protestant Church also passed an agreement to support the West German authorities should it be agreed that an extension to the Statute was necessary - see 'Verjährung von NS-Verbrechern', Landesynode (1964).

29 'NS-Verbrechen', Der Spiegel, no. 11 (1965). In December 1964, the matter was also debated on a special television programme questioning whether murderers really were 'still among us' - Grossman, Digest on Germany and Austria.

${ }^{30}$ Marcuse, Legacies of Dachau, 214-215.

31 TNA FO371/183153 RG1661/3: Effect of the German Statute of Limitations on the Future Prosecution of Nazi Criminals, 4 January 1965.

${ }^{32}$ Eleonore Sterling, 'What Germans Know About Nazi Crimes', Jewish Chronicle (13 November 1964).

${ }^{33}$ Buscher, "II Know I Also Share the Guilt", 253.

${ }^{34}$ Elisabeth Noelle and Erich Peter Neumann (eds), Jahrbuch der öffentlichen Meinung, 1965-1967

(Allensbach: Institut für Demoskopie, 1967), 165.

${ }^{35}$ Institut für Demoskopie, 'Verjährung von NS-Verbrechen', (Allensbach, 5 May 1965).

${ }^{36}$ LMA ACC/3121/E4/470, Wickert Institute, Tubingen (October 1964).

${ }^{37}$ DIVO, 'Bekanntheitsgrad des Auschwitz-Prozesses und Einstellung der Bundesbürger zu seiner

Durchführung zwanzig Jahre danach', DIVO Pressedienst July I-II (1964).

${ }^{38} 54$ per cent of those questioned by the IfD explained their hesitancy towards the Statute on these grounds, doubting the ability of the courts to uncover the facts so long after the events concerned - 'Verjährung von NSVerbrechen', (Allensbach, 5 May 1965).

${ }^{39}$ Helge Grabitz, 'Problems of Nazi Trials in the Federal Republic of Germany', Holocaust and Genocide Studies, 3, no. 2 (1988), 209.

${ }^{40}$ Institut für Demoskopie, 'Verjährung von NS-Verbrechen', (Allensbach, 5 May 1965).

${ }^{41}$ See, for example: 'Adenauer is Worried', Jewish Chronicle (17 March 1961); 'Dr Adenauer's Misgivings over Eichmann Trial', The Times (11 March 1961); 'Amerikaner über Deutsche', Frankfurter Rundschau (5 May 1961).

42 TNA FO1042/254: A.W. Rhodes to D.N. Beevor, 4 March 1964.

${ }^{43}$ Both the Paris and Los Angeles demonstrations were organised by Jewish groups. The former attracted some 2,000 people; Los Angeles 300. For details, see: LMA Paris Mass Meeting Protests against Statute of Limitations (9 December 1964); TNA FO371/183153 RG1661/14: Statute of Limitations Expiry Protest March on German Consulate General (19 January 1965); 'German Consulate Pickted over Law', Herald Examiner (15 January 1965).

44 TNA FO371/183153: Germany RG1661/42: Letter from Wastrich to Ennals (January 1965); FO371/154294:

War Criminals 1960: WG1662/8 Report from Foreign Office to Bonn, (5 May 1965).

${ }^{45}$ Grossman, Digest on Germany and Austria.

${ }^{46}$ Simon Wiesenthal, Verjährung? 200 Persönlichkeiten des öffentlichen Lebens sagen nein: eine

Dokumentation (Frankfurt am Main: Europäische Verlagsanstalt, 1965).

${ }^{47}$ East-West tensions on the extent of the Federal Republic's 'denazification' were exemplified by several scandals involving public figures such as Hans Globke and Theodor Oberlander. In 1965, the GDR also published the Brown Book, a list of former Nazis now holding prominent positions within the West German administration.

48 TNA FO371/183154: RG1661/31: Application of Statute of Limitations of War Crimes. Letter from B.G. Cartledge, British Embassy, Moscow to P.C. Holmer, Western Department, Foreign Office, London, 12 December 1965.

49 TNA FO371/183155 RG1661/69: Statement of the Government of the People's Republic of China, 24 March 1965.

${ }^{50}$ LMA ACC/3121/E4/470: Statute of Limitations: Statement by Richard Cardinal Cushing, Archbishop of Boston, 2 May 1965.

${ }^{51}$ Kurt R. Grossman, 'Trial of War Criminals - Decision Not to Extend Statute is Protested - Reader's Letter', New York Times (20 November 1964).

${ }^{52}$ Ernst Benda cited in 'The Limitations of a Statute', Jerusalem Post (6 September 1978). 
${ }^{53}$ For examples, see: Papers of the Institute of Jewish Affairs - University of Southampton Special Collections MS239/T3/45: War Crimes - Statute of Limitations; LMA Letters from the Board of Deputies of British Jews to the Centre de Documentation Juive Contemporaine, Paris and the Rijksinstituut, Amsterdam, 3 September 1964. ${ }^{54}$ TNA FO371/183153 RG1661/1: P.C.H. Holmer to A.W. Rhodes, 1 January 1965.

55 TNA FO371/183153 RG1661/18: Message of Protest from the Association of War Invalids Against Nazism, Tel Aviv, 20 January 1965.

56 TNA FO371/183153 RG1661/33: Prague Embassy Handed a Note Protesting against the Statute of

Limitations, February 1965.

${ }^{57}$ Ibid.

58 'Prosecution of War Crimes', Guardian (14 December 1964).

59 TNA FO371/183153 RG1661/24: Letter from National Union Furniture Trade Operatives, London to H.

Wilson, 28 January 1965.

${ }^{60}$ Hansard: 'West Germany (Prime Minister's Visit)', HC Deb 19 January 1965 Vol. 705 cc36-7W, 36W; 'Prime Minister and Dr Erhard (Talks)', HC Deb 09 February 1965 Vol. 706, cc194-7, 194.

${ }^{61}$ TNA FO 371/183153 RG1661/1: 'Effect of the German Statute of Limitations on the Future Prosecution of Nazi Criminals’, Foreign Office Minute by W.B.J. Ledwidge, 4 January 1965.

${ }^{62}$ David Cesarani \& Eric J. Sundquist (eds), After the Holocaust: Challenging the Myth of Silence (New York: Routledge, 2012).

63 TNA PREM13/337: Germany 1965 - Letter from H. Wilson to B. Janner, 22 March 1965. For Janner's original request, see FO371/183155 RG1661/52: Memorandum to the Prime Minister by Barnett Janner, 5 March 1965.

64 TNA PREM13/337: PM's Talk with Chancellor Erhard in Bonn, 8 March 1965. This meeting may have convinced Wilson that British intervention was actually unnecessary - Erhard assured him of his own desire to extend the Statute, and his belief that there would be an 'overwhelming parliamentary majority' in favour of further trials.

65 TNA FO371/183154 RG1661/23: MOD Check on Nazi Crime Documents, Minutes, 15 February 1965.

${ }^{66}$ Ibid., Memorandum from W.B.J. Ledwidge to J.T. Williams, 9 February 1965.

${ }^{67}$ TNA Communiqué by the Soviet Minister of Foreign Affairs, published in Pravda, 17 January 1965.

${ }^{68}$ LMA, ACC/3121/E4/470: Letter from Workers' Circle Friendly Society, London to Barnett Janner, Chair of the Foreign Affairs Committee, Board of Deputies of British Jews, 4 January 1965; Letter from Louis Saipe, Secretary Leeds Jewish Representative Council to A.G. Brotman, Board of Deputies of British Jews, 9 February 1965.

${ }^{69}$ Ibid, Motion by Marcus Shloimovitz to the Board of Deputies of British Jews, 20 December 1964.

${ }^{70}$ Ibid. See also: Letter from Hyman Wagner, Secretary for the Council of Manchester and Salford Jews to

A.G. Brotman, 12 December 1965 and correspondence between Lily Douglas, Secretary of the Memorial

Committee and the Board of Deputies in the same collection.

${ }^{71}$ Rüter and de Mildt, Justiz und NS-Verbrechen Register zu den Bänden I-XXII and Vorläufiges

Verfahrensregister zu den Banden XXIIIff (Amsterdam: APA Holland University Press, 1998).

72 Institute of Jewish Affairs, 'Tracking down the Nazi Criminals', Survey of the German Press, no. 34 (1 September 1967).

${ }^{73}$ For further details, see Institute of Jewish Affairs, Statute of Limitations and the Prosecution of Nazi Crimes in the Federal German Republic. Background Paper No. 14 (London: Institute of Jewish Affairs, July 1969); Devin O. Pendas, The Frankfurt Auschwitz Trial, 1963-1965: Genocide, History and the Limits of the Law (Cambridge: Cambridge University Press, 2006): 556-571.

${ }^{74}$ Wittmann, Beyond Justice.

75 Monson, 'The West German Statute of Limitations', 605.

76 See: EMNID, 'Verjährung für NS-Verbrechen', EMNID-Informationen, no. 11 (1978); Sample, 'Sollen NSVerbrechen verjähren?', Umfrage (November, 1978); EMNID, 'Verjährung für NS-Verbrechen', EMNID-

Informationen, no. 2 (1979); Sample, 'Verjährung von NS-Verbrechen: Nach Holocaust ist jeder zweite dagegen', Umfrage (February 1979).

77 De Mildt, In The Name of the People, 30. The headline in the Swiss newspaper, Tages- Anzeiger, 'Verjährung seit Holocaust weniger popular' (30 March 1979) summed up the change in public mood. For further analysis on the impact of Holocaust, see: Jeffrey Herf, 'The "Holocaust" Reception in West Germany: Right, Center and Left', New German Critique, 19, no. 1 (1980): 30-52; Andreas Huyssen, 'The Politics of Identification: "Holocaust" and West German Drama', New German Critique, 19, no. 1 (1980): 117-136; Wolf Kansteiner, 'Nazis, Viewers and Statistics: Television History, Television Audience Research and Collective Memory in West Germany', Journal of Contemporary History, 30, no. 4 (2004): 575-598.

${ }^{78}$ See TNA FCO 33/4015- 19: War Criminals of the FRG. 
${ }^{79}$ Quoted, along with viewing statistics and examples of audience responses to Holocaust, in Federal German Embassy, The Impact of 'Holocaust', (London, 1 February 1979).

${ }^{80}$ TNA FCO 33/4015-19: War Criminals of the FRG.

${ }^{81}$ TNA FCO 33/4015: Official Report of the Parliamentary Assembly, Council of Europe 30th Ordinary Session (Third Part), 2 February 1979.

${ }^{82}$ TNA FCO 33/4015: Speech by Chancellor Helmut Schmidt in Cologne, 9 November 1978.

${ }^{83}$ TNA FCO 33/4015: Board of Deputies of British Jews to David Owen, 26 January 1979.

${ }^{84}$ C.C. Bright, British Embassy Bonn to C.J. Rawlinson, Western Department, Foreign and Commonwealth Office, 16 March 1979 and 15 February 1979.

${ }^{85}$ TNA FCO 33/4017: Bright to Rawlinson, 16 March 1979; FCO 33/4018: Summary of Bundestag Speeches, 29 March 1979.

${ }^{86}$ TNA FCO 33/4016: Lord Goronwy-Roberts to G. Brooks, Thanet East Constituency Labour Party, 28 February 1979.

${ }^{87}$ United Nations, 'Convention on the Non-Applicability of Statutory Limitations to War Crimes and Crimes against Humanity' (Opened 26 November 1968; entered into force 11 November 1970),

http://treaties.un.org/Pages/ViewDetails.aspx?src=TREATY\&mtdsg no=IV-6\&chapter=4\&lang=en $($ Accessed 22 April 2013); Council of Europe, 'European Convention on the non-applicability of statutory limitation to crimes against humanity and war crimes', CETS No. 082 (Opened 25 January 1974; entered into force 27 June 2003) http://conventions.coe.int/Treaty/Commun/QueVoulezVous.asp?NT=082\&CM=1\&CL=ENG Accessed 22 April 2013). On the history of the UN Convention, see: Miller, 'The Convention of the Non-Applicability of Statutory Limitations', passim.

${ }^{88}$ Rome Statute of the International Criminal Court, Article 29 (Adopted 17 July 1998, entered into force 1 July 2002), http://untreaty.un.org/cod/icc/statute/romefra.htm (Accessed 22 April 2013). 